\title{
Systematic Study and Review of Water Standards Requirement for Synthesis of Pharmaceutical Products
}

Chaitanya R Khadsan

B.Pharmacy -III, Anuradha College of Pharmacy, CHIKHLI - 443201 Dist-Buldana, Maharashtra, India.

\section{To Cite this Article}

Chaitanya R Khadsan, "Systematic Study and Review of Water Standards Requirement for Synthesis of Pharmaceutical Products", International Journal for Modern Trends in Science and Technology, 6(8): 277-284, 2020.

\section{Article Info}

Received on 26-July-2020, Revised on 09-August-2020, Accepted on 12-August-2020, Published on 25-August-2020.

\section{ABSTRACT}

Water is widely used as a raw material, ingredient, and solvent in the processing, formulation, and manufacture of pharmaceutical products, active pharmaceutical ingredients (APIs) and intermediates. Control of the quality of water throughout the production, storage and distribution processes, including microbiological and chemical quality, is a major concern.Water is a key ingredient used in many pharmaceutical and life sciences operations.

Water can be used in a variety of applications, some requiring extreme microbiological control and others requiring none. Pharmaceutical water production, storage and distribution systems should be designed, installed, commissioned, qualified and maintained to ensure the reliable production of water of an appropriate quality. It is necessary to validate the water production process to ensure the water generated, stored and distributed is not beyond the designed capacity and meets its specifications.

The microbiological and chemical testing for water used in pharmaceutical plant, conductivity testing establishes a sample's ability to conduct electricity, which relates to the number of dissolved salts (ions) in the sample, a high ion count, lowers water purity and may indicate a processing problem. Total organic compounds (TOC) testing finds whether carbons in the sample are maintained below permissible limit of 500 parts per billion (ppb), biological burden testing establishes the number of microorganisms in a water sample, Microbial test of water includes the estimation of the number of viable aerobic bacteria present in a given quality of water.

KEYWORDS: Drinking water, water for injection, Total Organic Carbon, Different grades of water

\section{INTRODUCTION}

Water is a key ingredient used in many pharmaceutical and life sciences operations. Water is extensively used as a raw material, ingredient, and solvent in the processing, formulation, and manufacture of pharmaceutical products, active pharmaceutical ingredients (APIs) and intermediates. Water used for the production of pharmaceutical products whether for washing equipment, rinsing containers or as an analytical reagents, must meet quality requirements as dictated in standards published by the United States Pharmacopeia (USP), Pharmacopeia Europa (EP). Water has unique chemical properties due to its polarity and hydrogen bonds. This means it is able to dissolve, absorb, adsorb or suspend many different compounds. These include contaminants that may represent hazards in themselves or that 
may be able to react with intended product substances, resulting in hazards to health. Control of the quality of water throughout the production, storage and distribution processes, including microbiological and chemical quality, is a major concern.

The waters can be used in a variety of applications, some requiring extreme microbiological control and others requiring none. The needed microbial specification for a given bulk water depends upon its use. Microbial specifications are typically assessed by test methods that take at least 48 to 72 hours to generate results. Because pharmaceutical waters are generally produced by continuous processes and used in products and manufacturing processes soon after generation, the water is likely to have been used well before definitive test results are available. Failure to meet a compendia specification would require investigating the impact and making a pass/fail decision on all product lots between the previous sampling's acceptable test result and a subsequent sampling's acceptable test result. To ensure adherence to certain minimal chemical and microbiological quality standards, water used in the production of drug substances or as source or feed water for the preparation of the various types of purified waters must meet the requirements of the National Primary Drinking Water Regulations (NPDWR) (40 CFR 141) issued by the U.S. Environmental Protection Agency (EPA) or the drinking water regulations of the European Union or Japan, or the WHO drinking water guidelines.

Different grades of water quality are required depending on the route of administration of the pharmaceutical products. Other sources of guidance about different grades of water can be found in pharmacopoeias and related documents. Pharmaceutical water production, storage and distribution systems should be designed, installed, commissioned, qualified and maintained to ensure the reliable production of water of an appropriate quality. It is necessary to validate the water production process to ensure the water generated, stored and distributed is not beyond the designed capacity and meets its specifications.

\section{TYPES OF WATER}

There are many different grades of water used for pharmaceutical purposes. Several are described in USP monographs that specify uses, acceptable methods of reparation, and quality attributes. These water can be divided into two general types: bulk water, which are typically produced on site where they are used; and packaged water, which are produced, packaged, and sterilized to preserve microbial quality throughout their packaged shelf life. There are several specialized types of packaged water, differing in their designated applications, packaging limitations, and other quality attributes. There are also other types of water for which there are no monographs. These are all bulk waters, with names given for descriptive purposes only. Many of these water are used in specific analytical methods.

Drinking water can be referred as Potable Water. Drinking water must comply with the quality attributes of either the NPDWR, or the drinking water regulations of the European Union or Japan, or the WHO Drinking Water Guidelines. It may be derived from a variety of sources including a public water utility, a private water supply (e.g., a well) or a combination of these sources. The condition of the source water will dictate the treatment required to render it safe for human consumption (drinking). Drinking Water may be used in the early stages of cleaning pharmaceutical manufacturing equipment and product-contact components. Drinking Water is also the minimum quality of water that should be used for the preparation of official substances and other bulk pharmaceutical ingredients. Drinking water should be supplied under continuous positive pressure in a plumbing system free of any defects that could lead to contamination of any product. Typical treatment includes desalinization, softening, removal of specific ions, particle reduction and antimicrobial treatment. Drinking Water are generally considered safe for use for official substances and other drug substances.

\section{Production -}

Drinking water is derived from a raw water source such as a well, river or reservoir. There are no prescribed methods for the treatment of raw water to produce drinking-water from a specific raw water source. Typical processes employed at a user plant or by a water supply authority include:

- Desalinization.

- Filtration.

- Softening.

- Disinfection or sanitization (e.g. by sodium hypochlorite (chlorine) injection).

- Iron (ferrous) removal.

- Precipitation. 
- Reduction of concentration of specific inorganic and/or organic materials.

The drinking water quality should be monitored routinely to account for environmental, seasonal or supply changes which have an impact on the source water quality.

Equipment and systems used to produce drinking water should be able to be drained and sanitized. Storage tanks should be closed with appropriately protected vents, and should allow for visual inspection and for being drained and sanitized. Distribution pipe work should be able to be drained or flushed and sanitized. Special care should be taken to control microbiological contamination of sand filters, carbon beds and water softeners. Once microorganisms have infected a system, the contamination can rapidly form biofilms and spread throughout the system. Techniques for controlling contamination such as back flushing, chemical and/or thermal sanitization and frequent regeneration should be considered as appropriate.

\section{Purified Water-}

Purified Water is used as an excipient in the production of non-parenteral preparations and in other pharmaceutical applications, such as cleaning of certain equipment's and non-parenteral product-contact components. Purified Water must meet the requirements for ionic and organic chemical purity and must be protected from microbial contamination. The source or feed water for the production of Purified Water is Drinking Water. It should also be protected from recontamination and microbial proliferation.

\section{Production-}

Purified water is commonly produced by ion exchange, reverse osmosis (RO), ultrafiltration or electro deionization processes and distillation. Ambient temperature systems such as ion exchange, RO and ultrafiltration are especially susceptible to microbiological contamination. It is essential to consider the mechanisms for microbiological control and sanitization.

- Control of temperature in the system by heat exchanger or plant room cooling to reduce the risk of microbial growth (guidance value $<25^{\circ} \mathrm{C}$ ).

- Provision of ultraviolet disinfection.

- Selection of water-treatment components that can periodically be thermally sanitized.

- Application of chemical sanitization (including agents such as ozone, hydrogen peroxide and/or peracetic acid); - thermal sanitization at $>65{ }^{\circ} \mathrm{C}$.

\section{Highly purified water-}

Highly purified water (HPW) should be prepared from drinking water as a minimum-quality feed-water. Highly purified water is a unique specification for water found only in the European Pharmacopoeia. This grade of water must meet the same quality standard as water for injections (WFI), including the limit for endotoxins, but the water-treatment process used may be different. Current production methods include, for example, double-pass RO coupled with other suitable techniques such as ultrafiltration and deionization. HPW may be prepared by a combination of different methods such as RO, ultrafiltration and deionization. HPW should also be protected from recontamination and microbial proliferation.

\section{Production-}

Highly purified water (HPW) can be produced by double pass reverse osmosis coupled with ultrafiltration or by any other appropriate qualified purification technique or sequence of techniques. It is essential to consider the mechanisms for microbiological control and sanitization.

- Control of temperature in the system by heat exchanger or plant room cooling to reduce the risk of microbial growth (guidance value $<25^{\circ} \mathrm{C}$ ).

- Provision of ultraviolet disinfection.

- Selection of water-treatment components that can periodically be thermally sanitized.

- Application of chemical sanitization (including agents such as ozone, hydrogen peroxide and/or peracetic acid); - thermal sanitization at $>65^{\circ} \mathrm{C}$.

\section{Water for Injection-}

Water for injection (WFI) is used as an excipient in the production of parenteral and other preparations where product endotoxin content must be controlled, and in other pharmaceutical applications, such as cleaning of certain equipment and parenteral product-contact components. Water for injections should be prepared from drinking-water (usually with further treatment) or purified water as a minimum-quality feed water. WFI is not sterile water and is not a final dosage form. It is an intermediate bulk product and suitable to be used as an ingredient during formulation.WFI should also be protected from recontamination and microbial proliferation. 


\section{Production-}

Control of the chemical purity of WFI presents few major problems. The critical issue is ensuring consistent microbiological quality with respect to removal of bacteria \& bacterial endotoxin. Distillation has a long history of reliable performance \& can be validated as a unit operation, hence it currently remains the only official method for WFI.

WFI in bulk is obtained from water or from purified water by distillation in an apparatus of which the parts in contact with water are of neutral glass, quarts or suitable metal $\&$ which is fitted with an effective device to prevent the entrainment of droplets.

The correct maintenance of the apparatus is essential during production \& storage, appropriate measures are taken to ensure that the total viable aerobic count is adequately controlled \& monitored. WFI complies with test for purified water with additional

requirements for bacterial endotoxins (not more than 0.25 IU of endotoxin per $\mathrm{ml}$ ), conductivity $\&$ total organic carbon.

- Control of temperature in the system by heat exchanger or plant room cooling to reduce the risk of microbial growth (guidance value $<25^{\circ} \mathrm{C}$ ).

- Provision of ultraviolet disinfection.

- Selection of water-treatment components that can periodically be thermally sanitized.

- Application of chemical sanitization (including agents such as ozone, hydrogen peroxide and/or peracetic acid); - thermal sanitization at $>65{ }^{\circ} \mathrm{C}$.

\section{Water Quality Specifications for Pharmaceutical Water-}

The USP and EP have adopted similar standards for the quality of Bulk Pharmaceutical Waters, as illustrated in Table. In addition to PW and WFI, the table also shows a grade called Highly Purified Water (HPW), as defined in EP and representing water meeting WFI specifications but produced by means other than distillation.

Table 1: Different standards of water

\begin{tabular}{|c|c|c|c|c|c|c|}
\hline \multirow{2}{*}{$\begin{array}{c}\text { Paramete } \\
\mathrm{r}\end{array}$} & \multicolumn{2}{|c|}{ Purified Water } & \multicolumn{2}{c|}{$\begin{array}{c}\text { Highly } \\
\text { Purified } \\
\text { Water }\end{array}$} & \multicolumn{2}{c|}{$\begin{array}{c}\text { Water for } \\
\text { Injection }\end{array}$} \\
\cline { 2 - 7 } & USP & $\begin{array}{c}\text { Ph } \\
\text { Eur } \\
\text { (bulk) }\end{array}$ & $\begin{array}{c}\text { US } \\
\text { P }\end{array}$ & $\begin{array}{c}\text { Ph } \\
\text { Eur } \\
\text { (bulk) }\end{array}$ & USP & $\begin{array}{c}\text { Ph } \\
\text { Eur } \\
\text { (bulk) }\end{array}$ \\
\hline $\begin{array}{c}\text { TOC (ppb } \\
\text { C) }\end{array}$ & 500 & 500 & NA & 500 & 500 & 500 \\
\hline
\end{tabular}

\begin{tabular}{|c|c|c|c|c|c|c|}
\hline $\begin{array}{l}\text { Conductiv } \\
\text { ity@ } 20^{\circ} \mathrm{C}\end{array}$ & NA & $\begin{array}{c}\leq 4.3 \\
\mu \mathrm{S} / \mathrm{c} \\
\mathrm{m}\end{array}$ & NA & $\begin{array}{c}\leq 1.1 \\
\mu \mathrm{S} / \mathrm{c} \\
\mathrm{m}\end{array}$ & NA & $\begin{array}{c}\leq 1.1 \\
\mu S / c \\
m\end{array}$ \\
\hline $\begin{array}{l}\text { Conductiv } \\
\text { ity @ } 25^{\circ} \mathrm{C}\end{array}$ & $\begin{array}{c}\leq 1.3 \\
\mu \mathrm{S} / \mathrm{c} \\
\mathrm{m}\end{array}$ & NA & NA & NA & $\begin{array}{c}\leq 1.3 \\
\mu \mathrm{S} / \mathrm{c} \\
\mathrm{m}\end{array}$ & NA \\
\hline $\begin{array}{c}\text { Nitrate } \\
\text { (NO2) }\end{array}$ & NA & $\begin{array}{l}\leq 0.2 \\
\mathrm{ppm}\end{array}$ & NA & $\begin{array}{l}\leq 0.2 \\
\mathrm{ppm}\end{array}$ & NA & $\begin{array}{l}\leq 0.2 \\
\mathrm{ppm}\end{array}$ \\
\hline $\begin{array}{c}\text { Heavy } \\
\text { Metals } \\
\text { (ppm as } \\
\mathrm{Pb})\end{array}$ & NA & $\begin{array}{l}\leq 0.1 \\
\mathrm{ppm}\end{array}$ & NA & NA & NA & NA \\
\hline $\begin{array}{l}\text { Aerobic } \\
\text { Bacteria }\end{array}$ & $\begin{array}{c}\leq 100 \\
\mathrm{CFU} / \\
\mathrm{ml}\end{array}$ & $\begin{array}{c}\leq 100 \\
\mathrm{CFU} / \\
\mathrm{ml}\end{array}$ & NA & $\begin{array}{c}\leq 10 \\
\mathrm{CFU} / \\
\mathrm{ml}\end{array}$ & $\begin{array}{c}\leq 10 \\
\mathrm{CFU} / \\
\mathrm{ml}\end{array}$ & $\begin{array}{c}\leq 10 \\
\mathrm{CFU} / \\
\mathrm{ml}\end{array}$ \\
\hline $\begin{array}{c}\text { Bacterial } \\
\text { Endotoxi } \\
\mathrm{ns} \\
(\mathrm{EU} / \mathrm{ml} \text { or } \\
\mathrm{IU} / \mathrm{ml})\end{array}$ & NA & NA & NA & $\leq 0.25$ & $\leq 0.25$ & $\leq 0.25$ \\
\hline
\end{tabular}

N/A - Not an applicable requirement

\section{Application to specific type of water to processes and dosage forms-}

Product licensing authorities specify the minimum grade of water for pharmaceutical use must be used during the manufacture of the different dosage forms or for different stages in washing, preparation, synthesis, manufacturing or formulation. The grade of water used should take into account the nature and intended use of the intermediate or finished product and the stage in the manufacturing process at which the water is used.

\section{Quality of water for pharmaceutical use-}

Validation and qualification of water purification, storage and distribution system are a fundamental part of GMP and form an integral part of the GMP inspection. The grade of water used at different stages in the manufacture of the active pharmaceutical ingredients and pharmaceutical products should be discussed. The grade of water used should take account of the nature and intended uses of the finished product and the stage at which the water is used.

The following tables provide some general examples for guidance.

\section{Water present as an excipient in the final formulation-}

Water is the most commonly used excipient in medicinal products. The minimum quality of water selected depends on the intended use of the product. Table 2 summarises the main categories of sterile products. WFI is required for those products intended for parenteral administration. For convenience the pharmaceutical industry often uses WFI for the preparation of ophthalmic, sterile nasal/ear and cutaneous preparation.In such situation, highly purified water represents a useful 
alternative with the added advantage of satisfying the industry's need for large volumes.

Table 2: Quality of water for sterile medicinal products

\begin{tabular}{|c|c|}
\hline $\begin{array}{c}\text { Sterile medicinal } \\
\text { products }\end{array}$ & $\begin{array}{c}\text { Minimum acceptable quality of } \\
\text { water }\end{array}$ \\
\hline parenteral & WFI \\
\hline ophthalmic & Highly Purified water \\
\hline Hemofiltration solutions & WFI \\
\hline Haemodiafiltration solution & WFI \\
\hline Peritoneal dialysis solution & WFI \\
\hline Irrigation solution & WFI \\
\hline Nasal/ear preparations & Highly Purified water \\
\hline Cutaneous preparations & Highly Purified water \\
\hline
\end{tabular}

The main categories of non-sterile dosage forms. With the exception of some nebuliser preparations, purified water is the acceptable grade of water for non- sterile products.

\section{Table 3: Quality of water for Non-sterile medicinal products}

\begin{tabular}{|c|c|}
\hline $\begin{array}{c}\text { Non-sterile medicinal } \\
\text { products }\end{array}$ & $\begin{array}{c}\text { Minimum acceptable quality } \\
\text { of water }\end{array}$ \\
\hline Oral preparations & Purified \\
\hline Nebuliser solutions & Purified $^{*}$ \\
\hline Cutaneous preparations & Purified** \\
\hline Nasal/ear preparations & Purified \\
\hline Rectal/Vaginal preparation & Purified \\
\hline
\end{tabular}

*In certain disease states eg. Cystic fibrosis, medicinal products administered by nebulisation are required to be sterile and nonpyrogenic. In such cases WFI or sterilised highly purified water should be used.

**For some products such as veterinary teat dips it may be acceptable to use potable water where justified and authorised taking account of the variability in chemical composition and microbiological quality.

\section{Water used during manufacture of active pharmaceutical ingredients and medicinal products excluding water present as an excipient in the final formulation-}

The acceptable grade of water will depend heavily on the stage at which it is to be used during manufacture, the subsequent processing step and the nature of the final products. Table 4 and 5 summarize the acceptable quality of water for manufacture of active pharmaceutical ingredients and for sterile and non-sterile medicinal products.

\section{Water used for cleaning/rinsing of equipment, containers and closures-}

In general, the final rinse used for the equipment, containers/closures should use the same quality of water as used in the final stage of manufacture of the API orused as an excipient in a medicinal product.

\section{Table 4: Quality of Water used during the manufacture of active pharmaceutical ingredients (APIs)}

\begin{tabular}{|c|c|c|}
\hline $\begin{array}{c}\text { Type of } \\
\text { manufacture }\end{array}$ & $\begin{array}{l}\text { Product } \\
\text { requirements }\end{array}$ & $\begin{array}{c}\text { Minimum } \\
\text { acceptable } \\
\text { quality of water }\end{array}$ \\
\hline $\begin{array}{l}\text { Synthesis of all } \\
\text { intermediates of } \\
\text { APIs prior } \\
\text { to final isolation } \\
\text { and purification } \\
\text { steps }\end{array}$ & $\begin{array}{c}\text { No requirement for } \\
\text { sterility or } \\
\text { apyrogenicity in API } \\
\text { or } \\
\text { the pharmaceutical } \\
\text { product in which it } \\
\text { will be used. }\end{array}$ & Potable water* \\
\hline $\begin{array}{l}\text { Fermentation } \\
\text { media }\end{array}$ & $\begin{array}{c}\text { No requirement for } \\
\text { sterility or } \\
\text { apyrogenicity in API } \\
\text { or } \\
\text { the pharmaceutical } \\
\text { product in which it } \\
\text { will be used. }\end{array}$ & Potable water* \\
\hline $\begin{array}{c}\text { Extraction of } \\
\text { herbals }\end{array}$ & $\begin{array}{l}\text { No requirement for } \\
\text { sterility or } \\
\text { apyrogenicity in API } \\
\text { or } \\
\text { the pharmaceutical } \\
\text { product in which it } \\
\text { will be used. }\end{array}$ & Potable water** \\
\hline $\begin{array}{c}\text { Final isolation and } \\
\text { purification }\end{array}$ & $\begin{array}{c}\text { No requirement for } \\
\text { sterility or } \\
\text { apyrogenicity in API } \\
\text { or } \\
\text { the pharmaceutical } \\
\text { product in which it } \\
\text { will be used. }\end{array}$ & Potable water* \\
\hline $\begin{array}{l}\text { Final isolation and } \\
\text { purification }\end{array}$ & $\begin{array}{c}\text { API is not sterile, but } \\
\text { is intended for use in } \\
\text { a sterile, } \\
\text { non-parenteral }\end{array}$ & Purified water \\
\hline
\end{tabular}




\begin{tabular}{|c|c|c|}
\hline & product & \\
\hline $\begin{array}{c}\text { Final isolation and } \\
\text { purification }\end{array}$ & $\begin{array}{l}\text { API is sterile and not } \\
\text { intended for } \\
\text { parenteral use }\end{array}$ & Purified water \\
\hline $\begin{array}{c}\text { Final isolation and } \\
\text { purification }\end{array}$ & $\begin{array}{c}\text { API is not sterile, but } \\
\text { is intended for use in } \\
\text { a sterile, } \\
\text { parenteral product }\end{array}$ & $\begin{array}{c}\text { Purified water } \\
\text { with an } \\
\text { endotoxin limit of } \\
0.25 \mathrm{EU} / \mathrm{ml} \text { and } \\
\text { control of } \\
\text { specified } \\
\text { organisms. }\end{array}$ \\
\hline $\begin{array}{c}\text { Final isolation and } \\
\text { purification }\end{array}$ & $\begin{array}{l}\text { API is sterile and a } \\
\text { pyrogenic }\end{array}$ & $\begin{array}{l}\text { Water for } \\
\text { injection }\end{array}$ \\
\hline
\end{tabular}

* purified water should be used where there are technical requirements for greater chemical purity; **the application would need to demonstrate that potential variations in the water quality, particularly with respect to mineral composition, would not influence the composition of the extract.

Table 5: Quality of Water used during manufacture of medicinal products

\begin{tabular}{|l|l|}
\hline Manufacture & $\begin{array}{l}\text { Minimum } \\
\text { acceptable quality } \\
\text { of water }\end{array}$ \\
\hline Granulation & Purified* \\
\hline Tablet coating & Purified \\
\hline $\begin{array}{l}\text { Used in formulation prior } \\
\text { to non-sterile lyophilisation }\end{array}$ & Purified \\
\hline $\begin{array}{l}\text { Used in formulation prior } \\
\text { to sterile lyophilisation }\end{array}$ & WFI \\
\hline
\end{tabular}

*For some veterinary premix products eg. Granulation concentrates it may be acceptable to use potable water where justified and authorised taking account of the variability in chemical composition and microbiological quality.

\section{Table 6: Quality of Water used for cleaning/rinsing.}

\begin{tabular}{|c|c|c|}
\hline $\begin{array}{c}\text { Cleaning/rinsing of } \\
\text { equipment, } \\
\text { containers, closures }\end{array}$ & Product type & $\begin{array}{c}\text { Minimum } \\
\text { acceptable } \\
\text { quality of water }\end{array}$ \\
\hline Initial rinse & $\begin{array}{c}\text { Intermediates and } \\
\text { API }\end{array}$ & Potable water \\
\hline Final rinse & API & $\begin{array}{c}\text { Use same quality } \\
\text { of water as used } \\
\text { in the API } \\
\text { manufacture }\end{array}$ \\
\hline Initial rinse including & Pharmaceutical & Potable water \\
\hline
\end{tabular}

\begin{tabular}{|c|c|c|}
\hline $\begin{array}{c}\text { clean in place (CIP) of } \\
\text { equipment, } \\
\text { containers and } \\
\text { closures, if } \\
\text { applicable }\end{array}$ & $\begin{array}{l}\text { products-non } \\
\text { sterile }\end{array}$ & \\
\hline $\begin{array}{l}\text { Final rinse including } \\
\text { CIP of equipment, } \\
\text { containers } \\
\text { and closures, if } \\
\text { applicable }\end{array}$ & $\begin{array}{l}\text { Pharmaceutical } \\
\text { products-non } \\
\text { sterile }\end{array}$ & $\begin{array}{l}\text { Purified water or } \\
\text { use same quality } \\
\text { of water as used } \\
\text { in manufacture } \\
\text { of medicinal } \\
\text { product, if higher } \\
\text { quality than } \\
\text { purified water }\end{array}$ \\
\hline $\begin{array}{l}\text { Initial rinse* } \\
\text { including CIP of } \\
\text { equipment, } \\
\text { containers } \\
\text { and closures, if } \\
\text { applicable }\end{array}$ & Sterile products & Purified water \\
\hline $\begin{array}{l}\text { Final rinse } \\
\text { including CIP of } \\
\text { equipment, } \\
\text { containers } \\
\text { and closures, if } \\
\text { applicable }\end{array}$ & $\begin{array}{c}\text { Sterile } \\
\text { non-parenteral } \\
\text { products }\end{array}$ & $\begin{array}{l}\text { Purified water or } \\
\text { use same quality } \\
\text { of water as used } \\
\text { In manufacture } \\
\text { of medicinal } \\
\text { product, if higher } \\
\text { quality than } \\
\text { purified water }\end{array}$ \\
\hline $\begin{array}{l}\text { Final rinse }{ }^{* *} \\
\text { including CIP of } \\
\text { equipment, } \\
\text { containers } \\
\text { and closures, if } \\
\text { applicable }\end{array}$ & $\begin{array}{l}\text { Sterile parenteral } \\
\text { products }\end{array}$ & $\mathrm{WFI}^{* * *}$ \\
\hline
\end{tabular}

*some containers, eg. Plastic containers for eye drops may not need an initial rinse, indeed this may be counter-productive since particulate counts could be increased as a result. In some cases e.g. blow-fill-seal processes rinsing cannot be applied;

**If equipment is dried after rinsing with $70 \%$ alcohol, the alcohol should be diluted in water of the same quality as the water used for the final rinse;

***Where a subsequent depyrogenisation step is employed the use of highly purified water may be acceptable subject to suitable justification and validation data.

\section{Water storage and distribution system-}

The storage and distribution system should be considered as a key part of the whole system and should be designed to be fully integrated with the water purification components of the system. Water is one of the major commodities used by the pharmaceutical industry. It may be present as an excipient or used for reconstitution of the products during synthesis, production of the finished product or as cleaning agent for rinsing vessels, 
equipment, primary packaging materials etc. once water for pharmaceutical use has been obtained, it must be stored and distributed to the points of use, there is no point in producing quality water unless it is correctly stored and distributed. This stage is of vital importance to minimize possible contamination of the water and the proliferation of micro-organisms. Systems must be sealed with continuous recirculation and must have a sanitization systems. In this work the first stage is to automate the water storage $\&$ distribution for various requirements and control the level in the storage tank and monitoring the $\mathrm{PH}$, conductivity, temperature before distribution which is very important as any small change in this parameters may hinder the performance of the whole pharmaceutical plant. The next stage of the work is to control the flow rate of the water in the distribution line and then water is given to the UV treatment to minimize contamination and micro-organisms. The materials that come into contact with water for pharmaceutical use, including pipework, valves and fittings, seals, diaphragms and instruments, should be selected to satisfy the following objectives.

- Compatibility. The compatibility and suitability of the materials should encompass the full range of its working temperature and potential chemicals that will come into contact with the system at rest, in operation and during sanitization.

- Prevention of leaching. All materials that come into contact with water in pharmaceutical plant should be non-leaching at the range of working and sanitization, temperatures of the system.

- Corrosion resistance. Water used in pharmaceutical plant are highly corrosive.

\section{Microbiological test for water:}

The microbiological and chemical testing for Water used in pharmaceutical plant, Conductivity testing establishes a sample's ability to conduct electricity, which relates to the number of dissolved salts (ions) in the sample, high ion count lowers water purity and may indicate a processing problem. Total organic compounds (TOC) testing finds whether carbons in the sample are maintained below a mandated limit of 500 parts per billion (ppb), high is a reliable indicator of sample contamination. bioburden testing establishes the number of microorganisms in a water sample, ensuring bacterial loads don't exceed mandated USP levels.

These criteria required testing for the following.
- The bacteria Escherichia coli (E. coli)

- The bacteria Staphylococcus auseus (S. auseus)

- The bacteria Pseudomonas aeruginosa (Ps. Aeruginosa)

- The fungus Aspergillus niger (A. niger)

Microbial test of water includes the estimation of the number of viable aerobic bacteria present in a given quality of water.

\section{Procedure:}

- Transfer aseptically $1 \mathrm{ml}$ of the sample in each of two sterile petri dishes.

- Add to each dish approx. $20 \mathrm{ml}$ of sterile nutrient agar/ soyabean casein digest ager cover the petridishes and mix the sample with the agar by rotating the dishes 3 times both in clockwise and anti-clockwise directions.

- Allow the agar to solidify at room temperature.

- Invert the petridishes and incubate them at $37^{\circ} \mathrm{C}$ for $48 \mathrm{hrs}$.

- After incubation, examine the plates for growth and count the number of colony forming units in each plate.

- The average of both the readings is the total microbial count per $\mathrm{ml}$.

\section{FINANCIAL SUPPORT : NIL}

ACKNOWLEDGEMENT : Author is thankful to Principal and teacher guides of Anuradha College of Pharmacy, Chikhli for their encouragement, moral support and providing necessary library and laboratory facilities during study.

\section{REFERENCES}

[1] United States Pharmacopeia 35, General Chapter <1231>, United States Pharmacopoeial Convention, Inc. 12601 Twinbrook Parkway, Rockville, MD (2012).

[2] European Pharmacopoeia Edition 7 (EDQM.226. avenue de Colmar BP 907, F-67029 Strasbourg, France, 2011).

[3] The International Pharmacopoeia. Geneva, World Health Organization;

http://www.who.int/medicines/publications/pharmacop oeia/over view/en/index.html.

[4] WHO Guidelines for drinking-water quality, 3rd edition. Geneva, World Health Organization, 2008 http://www.who.int/water_sanitation_health/dwq/gdwq3 rev/en/index.html.

[5] WHO guidelines on good manufacturing practices: validation. In: WHO Expert Committee on Specifications for Pharmaceutical Preparations. Fortieth report. Geneva, World Health Organization, 2006, Annex 4 (WHO Technical Report Series, No. 937); 
http://www.who.int/medicines/publications/pharmprep/ TRS_937.pdf\#page $=119$.

[6] Guide to inspections of high purity water systems. Maryland, US Food and Drug Administration, 1993. http://www.fda.gov/ICECI/InspectionGuides.

[7] Water for Pharmaceutical use : Int. J. Pharm. Sci. Rev. Res., 36(1), January - February 2016; Article No. 35, Pages: 199-204 ISSN 0976 - 044X.

[8] Indian Standards : Reagent Grade Water - Specification ( Third Edition ) November-1996.

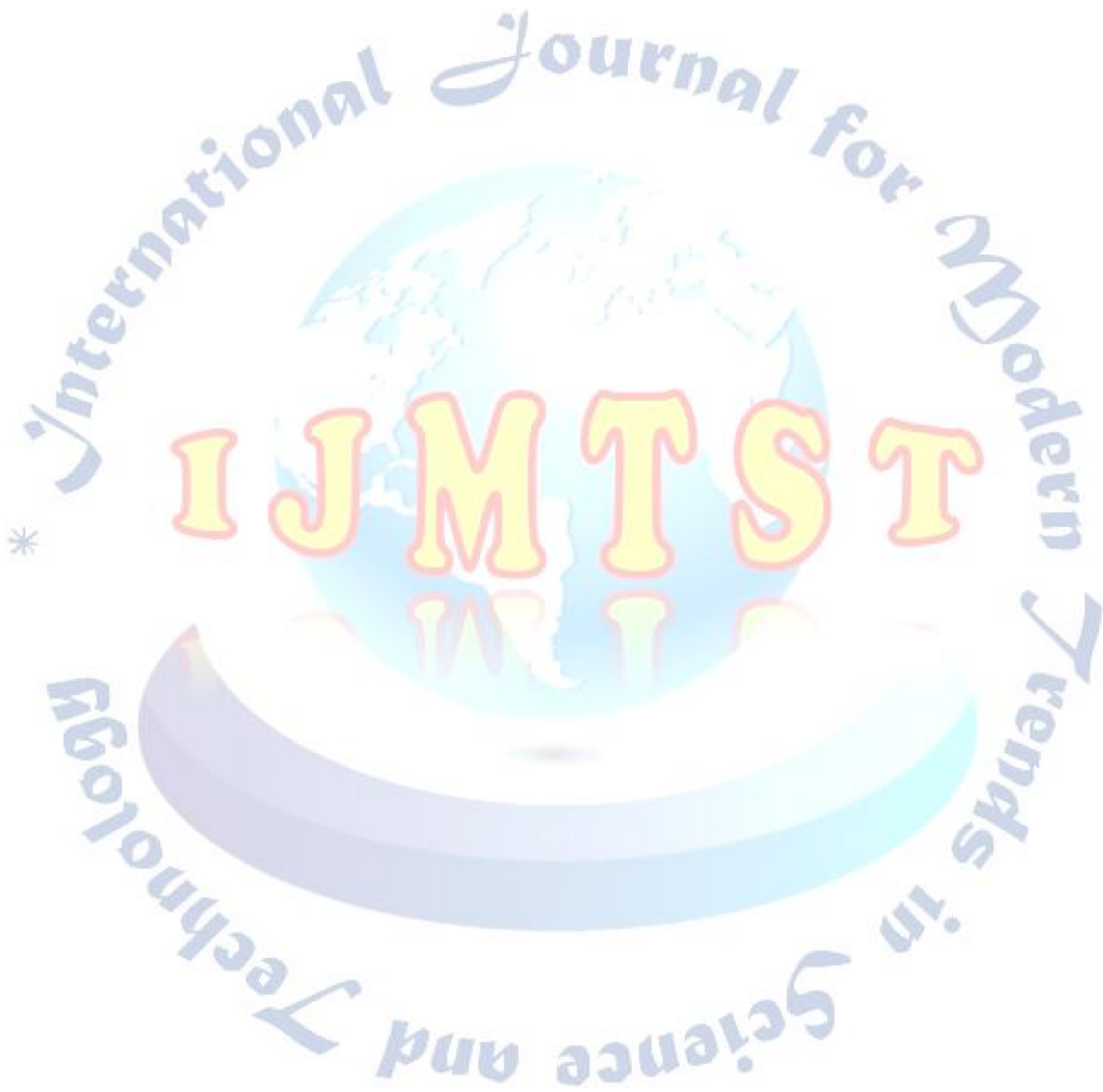

